\title{
Through a glass, darkly: long-term antiquities auction data
}

\section{in context}

\begin{abstract}
Analyses of long-term sales statistics acquired from auction catalogues are increasingly being used to characterise the trade in antiquities and assess the effectiveness of market control measures in reducing illicit trade. Most analyses to date have failed to account for other factors that might impact sales statistics, including business decisions taken by the auction houses themselves aimed at increasing profitability. By means of two case studies of long-term sales at Sotheby's auction house in New York, this paper argues that analyses of long-term sales data need to be better contextualised, using whatever information sources are available that might cast light upon auction house business practices. The commercial context of auction house business practices and their impact upon sales statistics should not be ignored.
\end{abstract}

Keywords: antiquities, Cambodia, Iraq, auctions, Sotheby's, illicit trade

\section{INTRODUCTION}

The information contained in the sales catalogues of major auction houses is increasingly being used to explore the inner workings of the antiquities market, and in particular to investigate the possible impact of legal and ethical market control measures on the 
antiquities trade. However, although many researchers have correlated apparent sales reductions with control policies or actions, none has provided a convincing causal argument linking the paired observations in such a way as to attribute unequivocally the dampening commercial impact of policies or actions aimed at market control. This paper takes a critical look at the use of catalogue information for investigating the antiquities market, and argues that market control measures are not the only nor perhaps even the most important factor influencing sales. The effects of business decisions aimed at increasing profitability cannot be ignored.

The sales catalogues of the auction houses Sotheby's, Christie's and Bonhams constitute a long-term, documentary record of antiquities appearing for sale on the market. Since the early 1980s, these catalogues have provided comprehensive descriptions of objects consigned for sale. The descriptions include information about likely date of manufacture of an object, its cultural and stylistic affiliations, its material and size, and occasionally a discussion of its aesthetic or historical importance. The descriptions sometimes (but not always) provide limited indications of provenance (ownership history), together with references to previous publications (if any), and a good quality image, often in colour. Catalogue estimates of likely price ranges are supplemented after the sale by a list of achieved prices. Over the long term, and taken together, the information provided in catalogues and their associated price lists can open a window onto the inner workings of the antiquities auction market, and by extension the broader antiquities market. In particular, it seems to offer the possibility of assessing reductions of sales and by extension trafficking volumes caused by legal or ethical regulation or other market control measures. 
The first use of long-term auction catalogue data for investigating the antiquities market was to establish some material estimates of the likely scale of illicit trade. Time series analyses of catalogues of Classical (ancient European, North African and Middle Eastern) antiquities demonstrated that the overwhelming majority of objects (generally in excess of 75 per cent) appearing in catalogues were being offered for sale without any indication of provenance, and almost always without any information regarding find spot. ${ }^{1}$ The implication was that most of these unprovenanced antiquities had arrived only recently on the market by illicit means. These early studies were important as they established some reliable, quantitative statistics describing the material volume of the antiquities trade and the likely involvement of auction houses in marketing trafficked material. Their findings were corroborated by media and police investigations of Sotheby's auction house in London, where staff were alleged to have been colluding with traffickers. ${ }^{2}$

In 2001, Elizabeth Gilgan offered a new direction when she demonstrated how auction sales data could be used to assess the direct or indirect impact of regulatory or other policy interventions on the antiquities market. ${ }^{3}$ (The term "sales data" is being used here to denote data relating to the auction sale itself, including sold and unsold lots, and is not restricted to sold lots only). Gilgan reported large quantities of Mesoamerican objects being offered at Sotheby's New York from 1971 to 1999. Within that time period, she identified a reduction in the number of objects offered from 1983 to 1987 . She suggested that it might have been caused by the US enactment of the 1983 Convention on Cultural Property Implementation Act (CPIA) and the 1987 US emergency import restrictions on antiquities from El Salvador. Gilgan went on to observe, however, that the decline was temporary: the number of Mesoamerican objects offered for purchase through auction houses recovered during the 1990s. This was in spite of the implementation of tougher 
regulatory policies including a more comprehensive CPIA Memorandum of Understanding (MOU) with El Salvador in 1995, the imposition of US emergency import restrictions on objects from the site of Sipán in Peru in 1990 and from the Petén area of Guatemala in 1991, and CPIA MOUs with both countries in 1997. ${ }^{4}$ As regards Maya objects, while none had information about find spot, 44 per cent listed a geographical or political area as a general place of discovery. From 1981 to 1991, Maya objects had been regularly attributed to the area of the Petén, which archaeologically would be understood to comprise northern Guatemala and the areas of Mexico and Belize immediately adjacent to the north and east. After 1991, however, which was the year US emergency import restrictions were imposed on objects from the Petén area of Guatemala, the term "Lowlands" came to be used to the almost complete exclusion of "Petén"5. Gilgan interpreted this as evidence that the 1991 import restrictions had politically sensitized the use of "Petén" and that Sotheby's had dissembled by substituting the geographical term "Lowlands" to draw customer attention away from the problematic origins of material being offered.

Gilgan's work suggested how long-term auction data might be used to measure the direct or indirect impact of regulation or other legal or ethical control measures upon the antiquities trade. With respect to direct impact, the argument was that market control diminishes sales volumes because of reduced material flows to the market. Indirect impact was expressed through changes in auction house practice or customer preference in reaction to developing measures of market control. Subsequent studies claimed to demonstrate the direct or indirect impact of United Nations Security Council Resolution (UNSCR) 1483 on auction sales of Iraqi material, ${ }^{6}$ of the 1999 US emergency import restrictions and 2003 CPIA MOU on auction sales of Cambodian material, ${ }^{7}$ and of CPIA MOUs with Guatemala (1997), Honduras (2004) and El Salvador (1995) on sales of 
Mesoamerican material. ${ }^{8}$ Such findings, however, were not consistent. Gordon Lobay failed to register any effect of the 2001 CPIA MOU with Italy on sales of central Italian material. ${ }^{9}$ These studies all used time series histograms to visualize changing sales volumes through time. More sophisticated statistical studies of price data using hedonic regression ${ }^{10}$ or longitudinal repeat-sales analyses ${ }^{11}$ have argued for the indirect impact of market control actions. They conclude that prosecutions and convictions of antiquities dealers have affected auction sales by placing a price premium on well-provenanced objects as customers seek reassurance that objects have not been recently trafficked.

A major weakness in these studies is that they impute causation to a demonstrated correlation through time between a reduction in sales volumes and hardening market control, but do not offer any empirical support for such a causal relation. They also fail to consider that there might be other structuring variables in play, particularly those relating to internal (company-specific) actions or policies that shape market demand and consumption. This empirical neglect is especially apparent in the case of Sotheby's, which has reported declining sales volumes across all departments since $2000 .^{12}$ For antiquities sales, Sotheby's own compliance specialists have explained this decline as a deliberate company response to developing legal and ethical norms. But against their testimony, there is also evidence to suggest that the sales decline stems from a deliberate commercial move by Sotheby's aimed at increasing profits. In an attempt to pick apart the causal roles of external market control and internal company practices in determining sales volumes, this paper will re-analyse Sotheby's New York sales of Iraqi and Cambodian material, presenting two case studies utilising time-series sales data for cylinder seals and Indian and Southeast Asian statuary. The sales data prepared for these case studies will be considered alongside contextualising information drawn from public sources, including statements made by officers of the 
Sotheby's compliance department and company practice as revealed in court documents.

The concluding discussion will draw upon the case studies to argue that it is difficult to identify the impact of market control measures on the antiquities auction market from only the evidence of sales data obtained from catalogues. The broader commercial and control environments of auction house antiquities sales must be taken into consideration by interpretations of sales data before any reliable conclusions can be reached.

Sotheby's catalogues have been chosen for these case studies because Sotheby's is a market leader, and this has two implications for researchers. First, for US-based scholars at least, the company's catalogues are widely available in university and museum libraries (though online records are becoming increasingly important). Most of the studies referenced above utilised catalogues from Sotheby's New York sales. Second, as a market leader, the company's public discourse and material actions can be taken as a measure of business practice within the antiquities market more generally. Two Sotheby's compliance officers have made public statements about company practice as regards provenance and due diligence, and two sets of court documents have revealed information about company practice as regards provenance and due diligence. Together, these sources can be used to contextualize and help investigate patterns seen in the sales data obtained from auction catalogues.

\section{DECLINING SALES VOLUMES AT SOTHEBY'S NEW YORK}

Since the late 1990s Sotheby's has moved towards offering a smaller number of highervalue consignments. This holds true across all departments. From 2002 to 2007, the company reduced the number of lots sold by auction from 160,000 to 85,000 , while over 
the same period the mean price of sold lots increased from $\$ 35,000$ to $\$ 50,000 .{ }^{13}$ These declining sales volumes can be demonstrated for different categories of antiquities sales. Figures 1 and 2 for example show declining sales of Classical antiquities and Indian and Southeast Asian antiquities. But although these sales declines have been reported for all categories of material, Sotheby's compliance officers have chosen to focus on antiquities alone, and explain the declines as evidence of strengthening and successful market control. In 2009, Jane Levine, who was at the time and in 2017 still was Worldwide Director of Compliance at Sotheby's, published her thoughts on provenance and the market. She stated that because of the developing international climate of legal and normative control, the market was gradually adopting stronger standards of provenance backed up by more rigorous due diligence - expressing her belief in the indirect impact of market control on Sotheby's business practices. While recognising the importance of national patrimony laws for determining ownership, she also pointed to the increasing salience of the 1970 UNESCO Convention on the Means of Preventing and Prohibiting the Illicit Import, Export and Transfer of Ownership of Cultural Property. There had been recent ratifications by major market countries such as the United Kingdom (2002) and Switzerland (2003). In 2008 the Association of Art Market Directors (AAMD) recommended 1970 as a provenance bright-line separating acceptable from unacceptable museum acquisitions. Levine argued that buyers were demanding better provenance and thus driving up prices for well-provenanced objects, with a growing consensus that 1970 should be the "gold standard" of acceptable provenance. ${ }^{14}$ In other words, there was increasing market demand for objects that could be shown to have been out of their country of origin before 1970 .

A few years later, in 2012, Sotheby's North American Compliance Counsel Elyse Dreyer commented on the decline in numbers offered at Sotheby's Mesoamerican sales 
after $1998 .{ }^{15}$ Echoing Levine, she stated that the decline reflected company policy to accept on consignment only material for which Sotheby's could "substantiate provenance going back far enough to satisfy our standards, which are, we believe, the most stringent in the market." ${ }^{16}$ She continued that this policy was not due to any particular piece of legislation or court case, but rather reflected the evolving international disapproval of illicit trade and Sotheby's own "commitment to being an ethical market player." ${ }^{17}$ Her statement asserts the indirect impact of market control measures on Sotheby's business practice as she describes the company moving to protect its reputation and assuage customer concern by reducing sales of potentially trafficked material.

Dreyer's assertion that sales volumes at Sotheby's had been declining because of the company's strengthening ethical stance was included in a paper by Marc Levine and Lucha Martínez de Luna investigating Mesoamerican sales at Sotheby's. ${ }^{18}$ But Marc Levine and de Luna also suggested that the reduction in Mesoamerican sales numbers might be indicative of a broader and commercially-motivated policy shift within Sotheby's towards selling smaller numbers of higher-priced objects, pointing out that while the number of Teotihuacan-style objects sold roughly halved during the 2000s, their average price more than doubled. ${ }^{19}$ This observation confirmed for Mesoamerican antiquities what had already been reported for all departments: since the late 1990s Sotheby's had been moving its business up-market across all departments.

Figures 1 and 2 show how this shift in business practice played out for Sotheby's Classical and Indian and Southeast Asian antiquities sales. Both departments gradually reduced the number of lots being offered for auction, while at the same time the mean price of sold lots held steady or increased. The company would have increased its profitability by reducing costs associated with marketing and handling a smaller volume of 
high-value material. If the declining sales volumes through the 2000s identified at Sotheby's for Classical, Asian and Mesoamerican antiquities were the outcome of a deliberate adoption of a more high-end sales strategy, then it undermines the statements of Jane Levine and Elyse Dreyer that they were due to the indirect impact of developing regulation and other control measures on the antiquities market. If targeted control measures were impacting upon antiquities sales only, there would not be similar sales declines reported across all company departments. Furthermore, if the sales reductions were due to a commercial move by Sotheby's to increase profits, and not (contrary to suggestions by the company's compliance department) as a response to mounting international concern about the harmful externalities of the antiquities trade, it calls into question the reliability and motivation of its compliance department's commentary and ultimately the company's moral integrity. These issues will be explored further through the two following case studies.

\section{CASE STUDY ONE: CYLINDER SEALS}

Previously published annual sales data from 1986 through to 2006 show that Sotheby's New York did not offer for sale any unprovenanced cuneiform tablets or cylinder seals after 2003. ${ }^{20}$ Both types of object are commonly found in Iraq and the present author argued in 2006 that the seeming cessation of sales was most likely due to the adoption in May 2003 of UNSCR 1483, which reaffirmed an international trade prohibition on Iraqi antiquities that was first introduced in August 1990 by UNSCR 661 (though largely ignored throughout the 1990s). Figure 3 presents an extended data run for cylinder seal sales alone, with annual statistics for all lots offered (provenanced and unprovenanced) by Sotheby's from 1985 to 
2013. ${ }^{21}$ Provenance has been assessed as verifiable provenance - the conjunction in a catalogue description of a name and a date. It is clear that by 2013 Sotheby's had still not resumed sales of cylinder seals, not even sales of seals that could be shown to have been out of Iraq before the 1990 date of UNSCR 661 or even the 1970 date of the UNESCO Convention.

The fact that no seals with a provenance dating back to before 1990 or 1970 were offered is surprising because before 2003 , most cylinder seals lots offered and sold at Sotheby's had a provenance strong enough to have placed them outside of Iraq by 1990 or even before 1970. The 1991 spike on the Figure 3 histogram, for example, marks the 12 December single owner sale of "The Ada Small Moore Collection of Ancient Near Eastern Seals." The collection had been assembled in the early twentieth century and published in 1940. The 1998 spike was due to the sale of the Erlenmeyer Collection of Western Asiatic Seals over the 4 June and 17 September "Antiquities and Islamic Art" sales. The Erlenmeyer Collection had been assembled between 1943 and the early 1960s. Presumably seals from these collections remained in circulation after 2003, or similar collections might have become available for auction, but if so, they were not sold at Sotheby's. The only cylinder seal lot Sotheby's offered after 2003 was lot 392 in the 9 December 2004 "Egyptian, Classical and Western Asiatic Antiquities" sale. Comprising eight seals, the provenance information provided was "From the collection of Charles Pankow." The main part of the Pankow collection had been sold the day before as the "Charles Pankow Collection of Ancient Art" sale, comprising Ancient Egyptian material with provenances ranging back to between 1938 and 1988. The single consignment of Pankow seals, therefore, was most likely accepted by Sotheby's as part of the larger and profitable agreement to sell the Egyptian material. 
In 2004, New York antiquities dealer Jerome Eisenberg wrote that Sotheby's "have announced that they will now generally accept only objects or lots with a minimum value of $\$ 5000 . " 22$ If Eisenberg was correct, presumably the decision was in line with the company's move towards selling better quality and higher-priced objects. Cylinder seals, however, are generally not very expensive, selling for prices in the hundreds rather than thousands of dollars. Often to increase price, several seals are sold together as one lot. The Ada Small Moore Seals were exceptional, with many selling for prices in excess of $\$ 10,000$, a high price of $\$ 143,000$, a mean price of $\$ 11,034$ and a median price of $\$ 3850$. But in the years before 2004, when Eisenberg reported the existence of the new policy, not many lots had sold for more than $\$ 5000$. The Erlenmeyer Collection lots achieved a mean price of $\$ 1511$ and a median price of $\$ 977$. Only three out of a total of 96 Erlenmeyer lots sold for more than $\$ 5000$, the highest price being a single seal which sold for $\$ 14,950$. The prices of the remaining 93 lots ranged from $\$ 230$ to $\$ 4667$. By way of comparison, the prices of all other lots of other types of antiquities sold in the 1998 sales ranged from $\$ 230$ to $\$ 398,500$, with a median of $\$ 3450$. Thus, in general, cylinder seals were a less profitable proposition for Sotheby's than other types of object. Over the four years following the 1998 Erlenmeyer sale, only three out of a total of 34 cylinder seal lots fetched more than $\$ 5000$. Lot 286 in the 8 December 2000 "Antiquities and Islamic Works of Art" sale comprised 5 seals with a provenance "North American private collection (assembled 1910-1932 and 1954)" and sold for $\$ 6,600$. Lot 221 in the 7 December 2001 “Egyptian, Classical and Western Asiatic Antiquities" sale comprised three seals with no provenance and sold for $\$ 7,200$. Lot 222 in the same sale comprising a single seal with the provenance "Hans Silvius von Aulock, Istanbul; Dr. Elie Borowski; Christie's, New York, June 13th, 2000, no. 550, illus."and previously published in 1952 sold for $\$ 5100$. Thus Sotheby's might have taken an active 
decision in 2003 to stop offering unprovenanced or poorly provenanced seals because of the trade prohibition of UNSCR 1483 , as the present author concluded in 2006 , but that cannot be deduced from the data presented in Figure 3 alone. The data might equally reflect the company's decision implemented in the early 2000 s to restrict sales to higherpriced objects, which would have excluded cylinder seals. If cylinder seals had been achieving higher prices, Sotheby's might have continued selling them after 2003. By way of contrast, sales volumes of cylinder seals at Christie's auction house in London also reduced immediately after 2003, but began to pick up again from 2009 onwards, though with most having a provenance stretching back to before the 1990 date of UNSCR $661 .{ }^{23}$ The fact that Sotheby's did not resume sales of similarly well-provenanced seals supports the argument being made here that the company's seeming decision to stop selling seals after 2003 was motivated more by commercial manoeuvring than by any ethical unease concerning origins.

\section{CASE STUDY TWO: CAMBODIAN STATUARY}

In 2011, Tess Davis published annual sales data for unprovenanced Cambodian antiquities offered by Sotheby's New York from 1988 through to $2010 .{ }^{24}$ Throughout the 1990s, Sotheby's had offered between 10 and 28 unprovenanced lots each year, but after 1999, for every year but one, that number dropped to four lots or fewer. Davis argued that this reduction in numbers was likely due to US emergency import restrictions on Cambodian material imposed in 1999, subsequently reaffirmed and strengthened in 2003 by the CPIA MOU between the United States and Cambodia.

If sales of Cambodian antiquities had been scaled down in response to targeted import prohibition, as Davis suggested, the same prohibition should not have affected 
consignments of similar material from other countries. Figure 2 shows the number of lots Sotheby's offered annually from 1998 to 2017 of comparable types of Cambodian, Indian and Thai statuary. By 2017, India and Thailand had not concluded MOUs with the United States, and so material from those countries would not have been subject to import control and might be considered as "control" groups for assessing the cause of the Cambodian reduction. The sharp drop after 1998 in the number of Cambodian objects offered annually identified by Davis is apparent, but it is there for all categories of material, including Indian and Thai, not just Cambodian. The total number of lots being offered declined progressively from 148 in 1998 down to 10 in 2016 and 2017, while after 2012 the number of Cambodian and Thai lots being offered dwindled almost to zero. The coincident reduction in sales of material from all countries cannot be due to import prohibition of Cambodian material only. There must be a different cause.

Table 1 presents provenance statistics for all lots of Cambodian and Indian material offered from 2001 to 2011. (The virtual absence of Cambodian lots after 2011 means that there are no comparative data for the following years). Provenance has been assessed as either verifiable provenance or published provenance. As previously defined, a verifiable provenance comprises a conjunction of a name and a date, so that theoretically the association can be investigated and the provenance verified. A published provenance comprises a date of previous publication, which allows the location of an object at a particular point in time to be established, and thus its likely legitimacy to be assessed. Of the two, published provenance is the strongest measure as it is the easiest to verify. Looking at Table 1, in terms of published provenance, there is little to choose between Indian and Cambodian material. For both groups, 84 per cent of objects have no provenance. For verifiable provenance, including lots with a published provenance, the situation is better for 
Cambodian objects, with 24 per cent having a provenance traced back to before 1970, but still with 57 per cent having no provenance. Only five per cent of Indian objects have a provenance tracing back to before 1970 and 76 per cent have no provenance. Only one Cambodian lot and one Indian lot have a post-1998 verifiable provenance. This difference in provenance provision between Cambodian and Indian material might be argued to reflect concern on the part of Sotheby's or its customers about the 1999 import restrictions on Cambodian material and following MOU, with Sotheby's responding by supplying more provenance information, or the 1970 date of the UNESCO Convention, and thus indicative of indirect effect on auction sales and perhaps the larger antiquities market of stronger market control. But still, with more than a half of objects offered lacking provenance, the Cambodian situation reveals continued indifference to the 1970 threshold. For India, it is worse.

Table 1. Provenance statistics for Indian and Cambodian statuary offered at Sotheby's 2001-2011. (All figures are percentages).

\begin{tabular}{|c|c|c|c|c|c|}
\hline & Cambodia & & & India & \\
\hline $\begin{array}{l}\text { Provenance } \\
\text { group }\end{array}$ & $\begin{array}{l}\text { Published } \\
\text { provenance }\end{array}$ & $\begin{array}{l}\text { Verifiable } \\
\text { provenance }\end{array}$ & $\begin{array}{l}\text { Verifiable } \\
\text { provenance } \\
\text { without } \\
\text { Spink }\end{array}$ & $\begin{array}{l}\text { Published } \\
\text { provenance }\end{array}$ & $\begin{array}{l}\text { Verifiable } \\
\text { provenance }\end{array}$ \\
\hline $\begin{array}{l}1969 \text { or } \\
\text { earlier }\end{array}$ & 4 & 24 & 10 & 2 & 5 \\
\hline 1970-1998 & 11 & 18 & 16 & 13 & 18 \\
\hline
\end{tabular}




\begin{tabular}{|l|l|l|l|l|l|}
\hline $1999-2017$ & 1 & 1 & 1 & 1 & 1 \\
\hline None & 84 & 57 & 73 & 84 & 76 \\
\hline
\end{tabular}

The Cambodian case study can be contextualised by information included in court documents filed in 2012 and 2016, which provides important insights into Sotheby's internal policy and practice as regards provenance and due diligence. The 2012 filing records that in April 2010, Sotheby's accepted a tenth-century Cambodian sandstone statue of Duryodhana on consignment from the widow of a Belgian collector who had bought it from the London company of Spink \& Son (Spink) in 1975. The Duryodhana had originally stood in the temple of Prasat Chen at Koh Ker in Cambodia's Preah Vihear Province. Sotheby's included the statue as lot 27 in its 24 March 2011 "Indian and Southeast Asian Works of Art" catalogue, headlined as "Property from the collection of a noble European lady" with a provenance "Spink \& Son Ltd London, 1975" and an estimated price of \$2 to \$3 million. On the day of the auction, the Secretary General of the Cambodian National Commission for UNESCO asked Sotheby's to stop the sale of the Duryodhana, and Sotheby's withdrew the object (while retaining possession of it). ${ }^{25}$ After the US Attorney for the Southern District of New York filed a civil forfeiture action against Sotheby's on behalf of Cambodia, an agreement was reached on 12 December 2013 between Sotheby's, the Belgian consignor and Cambodia that the Duryodhana would be returned to Cambodia, and it was returned in 2014.

The US Attorney's complaint alleged that the Duryodhana had been looted from Prasat Chen in or around 1972, before being acquired by the Bangkok-based dealer and collector Douglas Latchford, who had then conspired with Spink to "fraudulently" obtain export licences for the statue and other objects that might be shipped to Spink in the 
future. ${ }^{26}$ Spink subsequently sold the statue to the Belgian collector in 1975 . The complaint also alleged that Sotheby's expert advisor Emma Bunker, a researcher at Denver Art Museum, had advised Sotheby's that the statue was "definitely stolen" from Prasat Chen, but that the Cambodian authorities would be unlikely to claim it back ${ }^{27}$. Still, with no documentary evidence of provenance before 1975, Sotheby's went ahead and accepted the consignment.

The 2016 filing concerned New York dealer Nancy Wiener. It records that in September 2008, Wiener, together with the aforementioned Latchford, bought an eleventh-century Cambodian Baphuon Shiva from a "supplier" in Thailand for $\$ 250,000 .{ }^{28}$ They shipped the statue to London for cleaning and restoration and then on to New York. Wiener consigned the Shiva to Sotheby's New York where it was sold in the 24 March 2011 "Indian and Southeast Asian Works of Art" sale for $\$ 578,500$. The provenance provided in the catalogue was "Private English collection, acquired 1960s". Wiener told Sotheby's she had purchased the object from Spink around 1968, but that she had no written proof. ${ }^{29}$ Thus Sotheby's accepted the consignment on the assurance by Wiener of a (fictitious) purchase from Spink in the late 1960s and seemingly misrepresented by Sotheby's as a "private English collection".

Writing two years before this sale, Jane Levine had emphasised the need for due diligence to search out all material documentation of provenance, including insurance records, letters and family photographs, and that the objective of due diligence should be to confirm ownership back to before $1970 .{ }^{30}$ Sotheby's due diligence in 2011 when accepting the Baphuon Shiva on consignment differs from what Levine had recommended back in 2009, which deserves repeating in full. As regards verbal testimony, she said: 
Blind acceptance of verbal accounts without testing them for independent indicia or reliability would seem to fall below the standard of care called for under the new policies and likewise below a standard of care designed to weed out the legitimate objects from those that are likely the product of recent illegitimate looting. A genuine and good faith effort to document provenance would call for a critical assessment of the source of the verbal account. Is the source an interested party with a motive to create provenance? Can additional, independent and uninterested sources be identified to corroborate the verbal account? ${ }^{31}$

She argued that multiple, independent verbal accounts:

Would generally and reasonably be considered more persuasive than one lone verbal account from a single person standing to profit financially attesting that an object was in a private collection for the past 50 years. ${ }^{32}$

Nancy Wiener was in 2011 a well-established dealer in Asian Art in New York. She stood to profit from declaring - falsely - that the object had been in her private collection for the past forty years. Wiener was what Levine termed an "interested party", something she had explicitly warned should be guarded against. In accepting the consignment, Sotheby's failed to adhere to its own Worldwide Director of Compliance's stated standards of necessary due diligence.

These two consignments of Cambodian statuary, the Duryodhana and the Baphuon Shiva, call into question the due diligence of Sotheby's, which will be considered further below, but also highlight the past activities of Spink. Spink often turns up in the provenance listings of Asian objects. Established in 1772 as a coin dealership, Spink started selling Asian Art in the 1850 s. By the 1970 s and 1980s, it had become a clearinghouse for Asian antiquities, but never published comprehensive, illustrated catalogues of the type offered by Sotheby's and Christie's. Now, in consequence, it is difficult to ascertain what was sold at Spink or, if 
something was sold, how it arrived there. As Wiener showed, Spink can be used as an invented provenance of convenience - believable though unverifiable. Christie's bought Spink in 1993, and ended Spink's Asian sales in February 2000 before selling off what remained of the company in $2002 .^{33}$

The name "Spink" often appears for Cambodian objects as a component of a verifiable provenance, which would, in reality, be extremely difficult to verify. Revisiting the Cambodian statistics in Table 1, 16 of the lots with verifiable provenance list only Spink and a date, including 13 lots sold in the March 2010 "Indian and Southeast Asian Art" sale with a provenance described as "Spink in the 1960s". Accepting the idea that Spink might be provided as an invented provenance of convenience, not open to verification, and counting these lots instead as unprovenanced, the Cambodia statistics suffer accordingly (Table 1). Excluding Spink, more than 70 per cent of both Cambodian and Indian lots would have been offered for sale with no verifiable provenance. Worse still, if the name Spink is regarded as a red flag, likely evidence of illicit trade, then during the period 2001 to 2011 Sotheby's offered for sale 16 Cambodian lots with an overtly suspect provenance.

In 2009, Sotheby's Jane Levine suggested that the 1970 provenance threshold was becoming the "gold standard" of market acceptability. ${ }^{34}$ Sotheby's appears to have made some efforts to establish a pre-1970 provenance for the Baphuon Shiva and Duryodhana, but they were perfunctory. For the Baphuon Shiva, the company accepted the sole testimony of the seller. The dispute over the ownership and sale of the Duryodhana centered upon the date of the applicable Cambodian patrimony law, and its acceptability by US courts. The US attorney maintained that Cambodian ownership could be traced back to a 1900 decree $^{35}$ while Sotheby's defended accepting the consignment on grounds that 1993 
was the relevant date. ${ }^{36}$ The 1970 threshold - Levine's "gold standard" -was not considered by Sotheby's as materially relevant to the dispute. It would in any case be difficult to restrict trading to Cambodian objects out of Cambodia before 1970. Although many antiquities were taken out of the country during the French colonial period (1867-1953), most entered museums and are not available for circulation on the open market. Theft and trafficking increased during the 1960s, but it was not until after the outbreak of civil war in 1970 that the situation really deteriorated. ${ }^{37}$ The volume of trade that followed is reflected in US museum acquisitions, which increased during the 1970 s and later. ${ }^{38}$ By the 2000 s, then, there was not a sufficiently large number of Cambodian objects taken from the country before 1970 to sustain a market conforming to Levine's gold standard. The choice facing buyers and sellers was to trade in Cambodian objects that had most likely been trafficked after 1970, or to refrain from trading in Cambodian objects altogether.

Perhaps after the Duryodhana case, Sotheby's did become more circumspect about the provenance of Cambodian objects, though it is difficult to deduce that fact from auction data alone. Nancy Wiener's mother Doris Wiener, who died in April 2011, was also a prominent dealer in Asian Art. Acting as a co-executor after her mother's death, in late 2011, Nancy Wiener attempted to liquidate her mother's stock at Sotheby's. According to court records, Sotheby's rejected the consignment because she could not supply the documentation necessary to prove that the material had been outside countries of origin by the dates of the relevant patrimony laws. ${ }^{39}$ One reading of this rejection is that Sotheby's had changed its policy in the wake of the March 2011 Cambodian complaint about the projected Duryodhana sale and introduced stricter provenance or due diligence requirements, requiring materially demonstrable adherence to legally enforceable patrimony laws rather than to the normative 1970 threshold. Figure 2 shows that within the 
chronological limit of the study, Sotheby's did offer one Cambodian lot after 2012. It was a twelfth to thirteenth century sandstone head of a Buddha offered as lot 253 in the 15 March 2017 "Indian, Himalayan and Southeast Asian Works of Art" sale. The head had been deaccessioned by the Cleveland Museum of Art, which had acquired the piece in 1951 and published it in 1952. It sold for $\$ 60,000$. On the face of it, this consignment might conform to the 1970 standard. But equally, it would conform to the Sotheby's contention that the relevant patrimony law was enacted in 1993. But whether the conjectured 2011 internal company decision to stop selling anything but well-provenanced Cambodian antiquities could be deduced from the auction data alone is questionable. By 2013 , consignments to Asian Art auctions had reduced in number to such an extent that proportionally it would be expected that very few Cambodian objects would be offered anyway.

From what can be pieced together from catalogue data and the evidence of court documents, two things can be said about Sotheby's sales of Cambodian statuary. First, the decline in the number of Cambodian objects being offered by Sotheby's after 1998 was most likely due to the company's new business strategy of selling fewer but higher-priced objects. There is nothing to suggest in the cases of the Baphuon Shiva and Duryodhana that in 2010 the company was overly concerned about adhering to a 1970 provenance threshold or ensuring that consigned material had not been trafficked sometime during the preceding decades. Public statements by Sotheby's officers that the reduction in sales seen in longterm data reflected the company's response to developing control measures look to have been incorrect at best, or deliberately misleading at worst. The obvious violations of the 1970 gold standard show that Sotheby's public pronouncements on necessary provenance and due diligence were not supported by actual company practice. Second, it does look possible that after 2011, possibly because of the unwelcome media attention caused by the 
Cambodian claim on the Duryodhana, or perhaps because the Cambodian government clarified its willingness to work with US law enforcement authorities to recover trafficked material, Sotheby's did become more circumspect about what Cambodian material it was prepared to accept on consignment. If that was the case, the company was reacting to the clear and present danger of materially and reputationally damaging court actions, not to the more remote threat of international disapproval as expressed through developing ethical and legal controls, as claimed by its compliance department. In any case, this conjectured decision is not immediately obvious from a marked reduction in sales, which had already been in decline for many years.

\section{DISCUSSION}

A sales department of an auction house exists at the centre of multiple, overlapping environments, and its sales strategy is continually adjusting and readjusting in response to changes in those environments. Any examination of sales data must pay close attention to this environmental context. Closest to home is the company environment - competing departments within the same company. The quantities of material offered for sale by an auction house are constrained physically by the size of the company's premises and the time available for processing material. An individual department's business must be conducted within those relatively inelastic limitations of time and space, so that one department cannot easily expand without impacting upon the business of another department. Having said that, it would be in the company's interest to allow a more profitable department to expand at the expense of a less profitable one. But an individual department also competes in a commercial environment with similar departments or 
traders in other companies, which in Sotheby's case usually means Christie's. It seems likely that the post-2000 sales reductions seen in the cylinder seal and Indian and Southeast Asian statuary case studies relate to Sotheby's repositioning itself in the commercial environment vis-à-vis Christie's, with Sotheby's moving to capture the higher value market.

Regulatory and other market control measures aim directly at reducing the illicit flow of material and indirectly at reducing demand. These externally imposed ethical and legal constraints on trade, which are intended to discourage trafficking and protect cultural heritage at source, constitute the control environment. Demand, however, while responsive to the control environment, is fashioned and satisfied within the broader market environment. Demand is responsive to many considerations, including concerns about criminality and other forms of harmful action associated with theft and trafficking, but also cultural vagaries of fashion or taste and broadly economic factors such as the financial performance of stock or other asset classes. Thus market demand must to some extent respond to the control environment, but the nature of demand cannot be explained solely by market control. Cultural and economic factors also have a role to play.

Many if not most of the more recent studies of long-term auction sales data have aimed to investigate the direct or indirect impact of the control environment upon auction sales, and by extension upon the larger antiquities market. From the evidence presented here, however, there is little to suggest that Sotheby's had been responsive in material terms to control measures, until possibly after the failed sale of the Cambodian Duryodhana, with company public statements providing the appearance rather the substance of legal and normative compliance, and with the ultimate commercial goal of profitability prioritized over the desirability of harm reduction. Long-term sales data might open a window onto the inner-workings of the auction market, but it is a dark and distorting 
glass view and the inner-workings are complex. Care should be taken when interpreting the results of such studies, and where possible contextual information should be used to help the move from demonstrating a correlation between market control and sales volumes or prices towards establishing a causal relationship. It was reported in January 2016 that both Sotheby's and Christie's might be preparing to shift downmarket, across all departments, looking for the higher-volume, lower-priced business of the middle market ${ }^{40}$. It will be interesting to see whether the long-term antiquities sales declines demonstrated in this paper for Sotheby's goes into reverse. If it does, it will have little to do with the failure of market control measures, and a lot to do with the declining profitability of the high-end sales strategy Sotheby's had pursued since the end of the 1990s.

\section{ACKNOWLEDGMENTS}

The research on which this paper was based was supported by the European Research Council under the European Union's Seventh Framework Programme (FP7/20072013)/European Research Council Grant agreement no. 283873 GTICO. The writing of the paper was made possible by the support of Arcadia through the Endangered Archaeology in the Middle East and North Africa project of the University of Oxford's School of Archaeology.

\section{BIBLIOGRAPHY}

Beltrametti, Silvia, and James Marrone. 2016. “Market Responses to Court Rulings: Evidence from Antiquities Auctions." Journal of Law and Economics 59, no. 4: 913-944. 
Brodie, Neil. 2006. "Iraq 1990-2004 and the London Antiquities Market." In Archaeology, Cultural Heritage, and the Antiquities Trade, edited by Neil Brodie, Morag M. Kersel, Christina Luke and Kathryn W. Tubb, 206-26. Gainesville: University Press of Florida.

Brodie, Neil. 2008. "The Western Market in Iraqi Antiquities." In Antiquities Under Seige. Cultural Heritage Protection After the Iraq War, edited by Lawrence Rothfield, 63-74. Lanham: AltaMira.

Brodie, Neil. 2011. "Academic Involvement in the Market in Iraqi Antiquities." In Crime in the Art and Antiquities World: Illegal Trafficking in Cultural Property, edited by Stefano Manacorda and Duncan Chappell, 117-133. New York: Springer.

Brodie, Neil and Palmyre Manivet. 2017. “Cylinder Seal Sales at Sotheby’s and Christie's (1985-2013)." Journal of Art Crime no. 17: 3-16.

Brodie, Neil, and Jenny Doole. 2004. "The Asian Art Affair: US Art Museum Collections of Asian Art and Archaeology." In Material Engagements: Studies in Honour of Colin Renfrew, edited by Neil Brodie and Catherine Hills, 83-108. Cambridge: McDonald Institute.

Chippindale, Christopher, David W.J. Gill, Emily Salter and Christian Hamilton. 2001. "Collecting the Classical World: First Steps in a Quantitative History." International Journal of Cultural Property 10: 1-31. 
Davis, Tess. 2011. "Supply and Demand: Exposing the Illicit Trade in Cambodian Antiquities Through a Study of Sotheby's Auction House." Crime, Law and Social Change 56: 155-174.

Davis, Tess. 2015. "The Lasting Impact of United States vs Cambodian Sculpture”. In Countering Illicit Traffic in Cultural Goods, edited by France Desmarais, 95-106. Paris: International Council of Museums.

Davis, Tess and Simon Mackenzie. 2015. "Crime and Conflict: Temple Looting in Cambodia." In Cultural Property Crime: An Overview and Analysis of Contemporary Perspectives and Trends, edited by Joris D. Kila and Marc Balcells, 292-306.Leiden: Brill.

Eisenberg, Jerome. 2004. "The Autumn 2003 Antiquities Sales." Minerva 15, no. 2: 25-32.

Elia, Ricardo J. 2001. "Analysis of the Looting, Selling, and Collecting of Apulian Red-Figure Vases: a Quantitative Approach." In Trade in Illicit Antiquities: The Destruction of the World's Archaeological Heritage, edited by Neil Brodie, Jenny Doole and Colin Renfrew, 145-154. Cambridge: McDonald Institute.

Gerlis, Melanie. 2016. “Christie's and Sotheby's battle for the middle market." Art Newspaper, 1 February

Gilgan, Elizabeth. 2001. "Looting and the Market for Maya Objects: a Belizean Perspective." In Trade in Illicit Antiquities: The Destruction of the World's Archaeological Heritage, edited by Neil Brodie, Jenny Doole and Colin Renfrew, 73-88. Cambridge: McDonald Institute. 
Hauser-Schäublin, Brigitta. 2016. “Looted, Trafficked, Donated and Returned: The Twisted Tracks of Cambodian Antiquities." In Cultural Property and Contested Ownership, edited by Brigitta Hauser-Schäublin and Lyndel V. Prott, 64-81. London: Routledge.

Kiel, Katherine and Katherine Tedesco. 2011. Stealing History: How Does Provenance Affect the Price of Antiquities. College of the Holy Cross, Department of Economics Faculty Research Series, Paper no. 11-05.

Lafont, Masha. 2004. Pillaging Cambodia. Jefferson: McFarland.

Levine, Jane. 2009. "The Importance of Provenance Documentation in the Market for Ancient Art and Artifacts: The Future of the Market May Depend Upon Documenting the Past." DePaul Journal of Art, Technology and Intellectual Property Law 19, no. 2: 219-234.

Levine, Marc and Lucha Martínez de Luna. 2013. “Museum Salvage: A Case Study of Mesoamerican Artifacts in Museum Collections and on the Antiquities Market." Journal of Field Archaeology 38, no. 3: 264-276.

Lobay, Gordon. 2009. "Border Controls in Market Countries as Disincentives to Antiquities Looting at Source? The US-Italy Bilateral Agreement 2001." In Criminology and Archaeology, edited by Simon Mackenzie and Penny Green, 59-82. Oxford: Hart. 
Moncrieff, Elspeth. 2000. "Death of the Oldest Art Dealership in the World." Art Newspaper no. 101: 34.

Neiman, Peter. 2013. Memorandum of Law in Support of Claimant's Motion for a Judgment on the Pleadings and for a Stay of Discovery.

New York. 2016. The People of the State of New York against Nancy Wiener. Criminal Court of the City of New York, County of New York.

Nørskov, Vinnie. 2002. Greek Vases in New Contexts. Aarhus: Aarhus University Press.

Thompson, Don. 2008. The \$12 million Stuffed Shark. New York: Palgrave.

Watson, Peter. 1997. Sotheby's: Inside Story. London: Bloomsbury.

Watson, Peter and Cecilia Todeschini (2007) The Medici Conspiracy. New York: Public Affairs.

USA. 2012. United States of America v. A $10^{\text {th }}$ Century Cambodian Sandstone Sculpture, Currently Located at Sotheby's in New York, New York. United States District Court of New York. 
Figure 1. Total numbers of lots offered and sold each year at Sotheby's New York Antiquities sales from 1985 to 2013, together with the mean price of sold lots (USD).

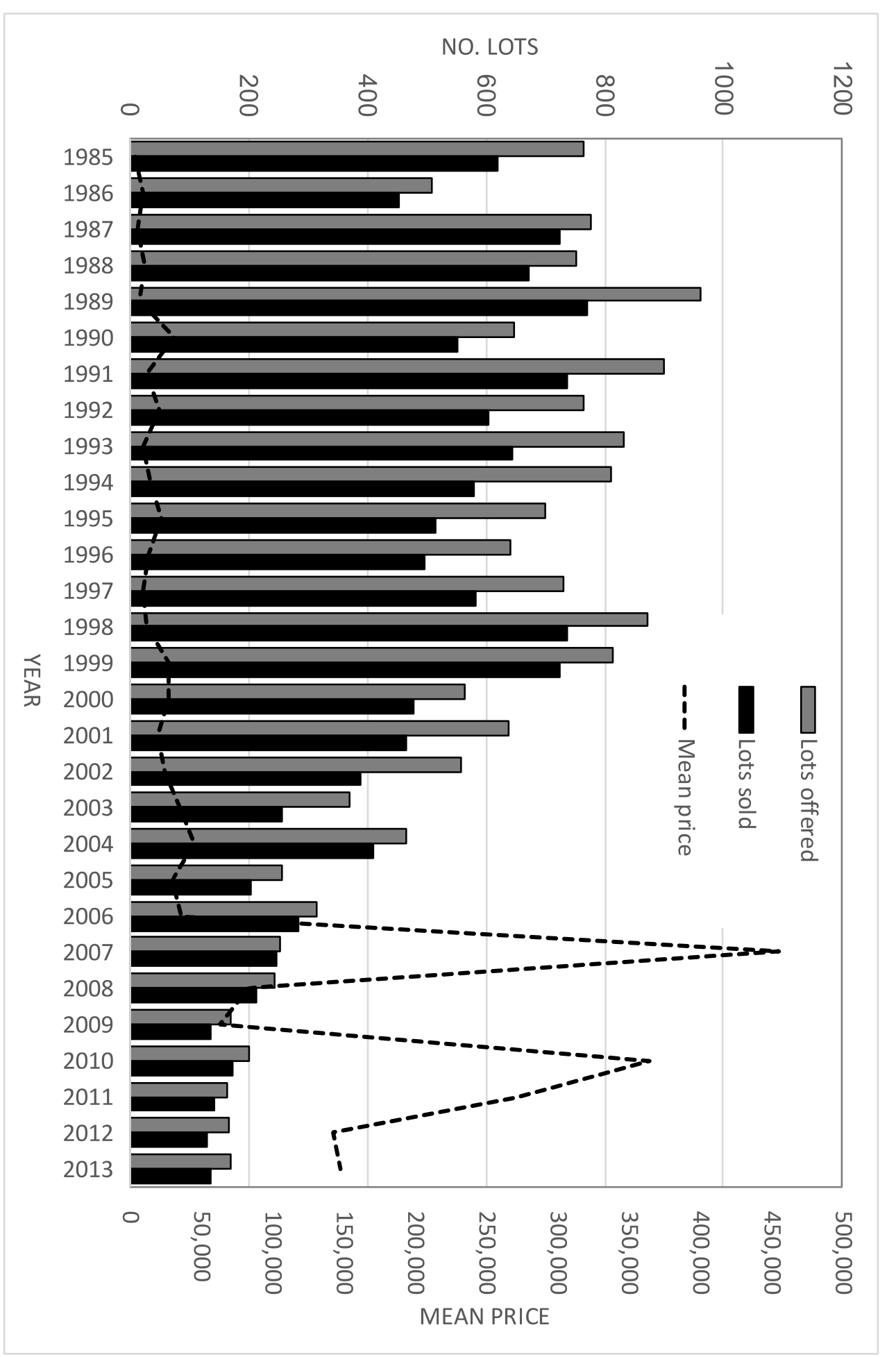


Figure 2. Total numbers of statuary lots from India, Cambodia and Thailand offered and sold each year at Sotheby's New York Indian and Southeast Asian Art sales from 1998 to 2017, together with the mean price of sold lots (USD). Only statuary dating from the eighth to fourteenth centuries included. No data for 2009.

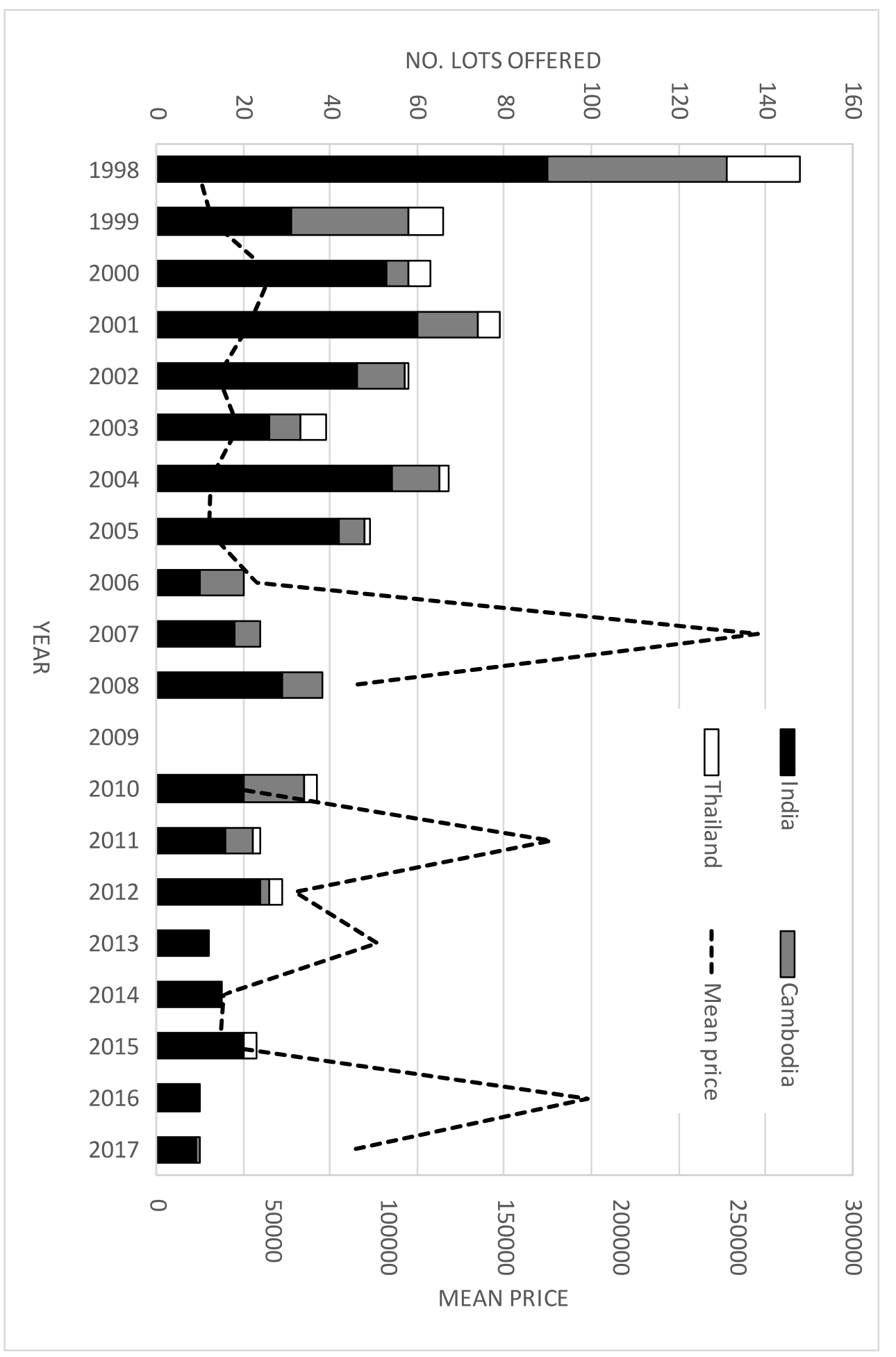


Figure 3. Total numbers of cylinder seal lots offered each year at Sotheby's New York Antiquities sales from 1984 to 2014, together with mean price (USD). No data for 1996. Histogram bars are shaded according to verifiable provenance classes.

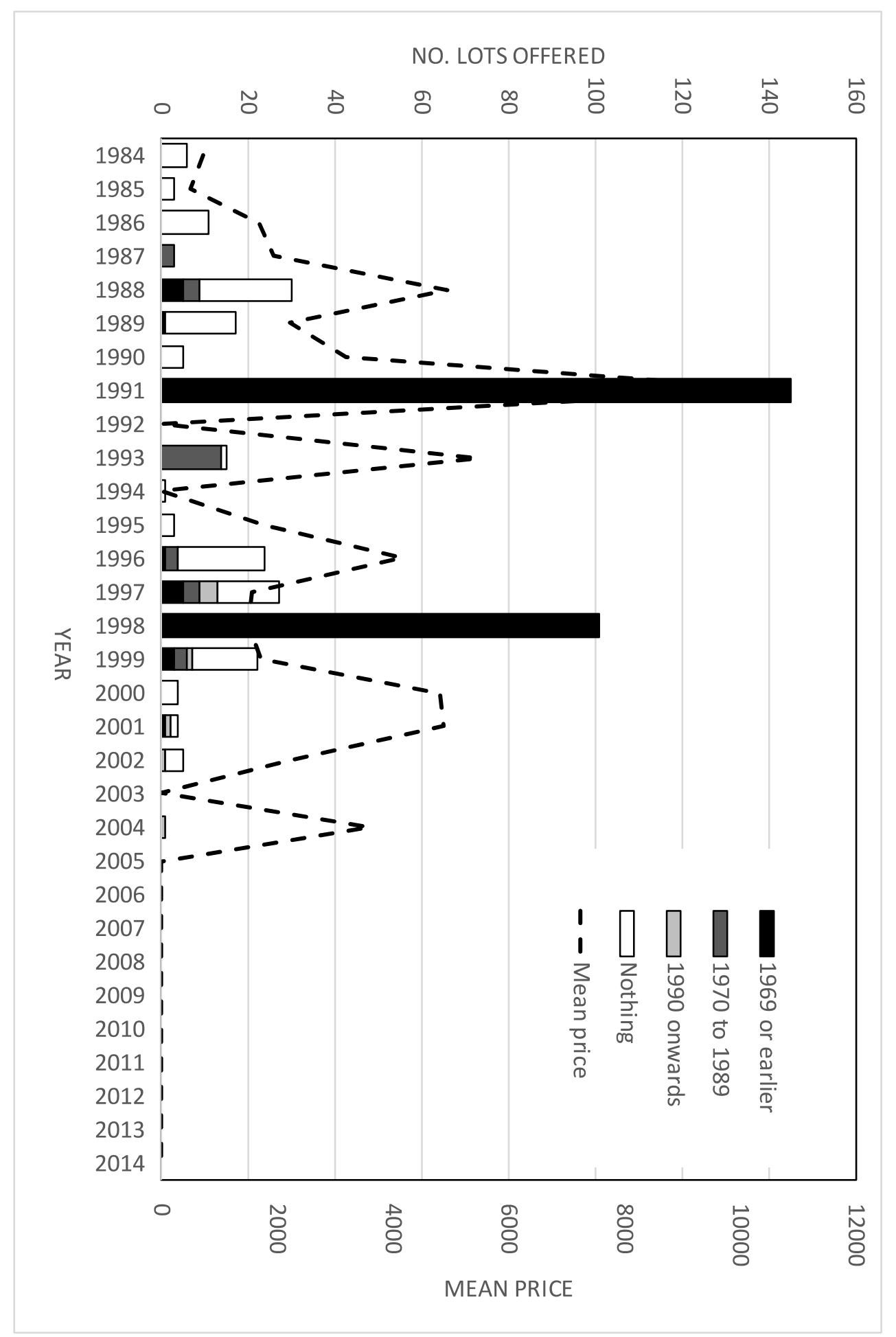


${ }^{1}$ Chippindale et al. 2001: 18-20; Elia 2001; Nørskov 2002: 256-261.

${ }^{2}$ Watson 1997; Watson and Todeschini 2007.

${ }^{3}$ Gilgan 2001: 78-83.

${ }^{4}$ Gilgan 2001: 80.

${ }^{5}$ Gilgan 2001: 81-82, 82 figure 9.6.

${ }^{6}$ Brodie 2006: 214-217; 2008: 64-69; 2011: 117-122.

7 Davis 2011.

${ }^{8}$ Levine and de Luna 2013.

${ }^{9}$ Lobay 2009: 61-64.

${ }^{10}$ Kiel and Tedesco 2011.

${ }^{11}$ Beltrametti and Marrone 2016.

12 Thompson 2008: 100.

13 Thompson 2008: 100.

${ }^{14}$ Levine 2009: 229-232.

${ }^{15}$ M. Levine and de Luna 2013.

16 Dreyer 2012, quoted in M. Levine and de Luna 2013: 269.

17 Dreyer 2012, quoted in M. Levine and de Luna 2013: 269.

18 M. Levine and de Luna 2013.

${ }^{19}$ M. Levine and de Luna 2013: 268.

${ }^{20}$ Brodie 2008: 64-69, 64 figure 6.1; Brodie 2011: 117-120, 119 figure 7.2.

21 Brodie and Manivet 2013.

22 Eisenberg 2004.

${ }^{23}$ Brodie and Manivet 2017: 7-8, 14 figures 7 \& 8.

24 Davis 2011.

25 Davis 2015; Hauser-Schäublin 2016; USA 2012.

26 USA 2012: 4.

27 USA 2012: 14-18.

${ }^{28}$ New York 2016: 2-3.

${ }^{29}$ New York 2016: 3.

30 Levine 2009: 13.

${ }^{31}$ Levine 2009: 232.

32 Levine 2009: 232.

33 Moncrieff 2000.

${ }^{34}$ Levine 2009: 229-232.

35 USA 2012: 25.

${ }^{36}$ Neiman 2013: 9.

37 Davis and Mackenzie 2015; Lafont 2004: 7-71.

${ }^{38}$ Brodie and Doole 2004: 98-100, 98 plate 7.9.

39 New York 2016: 6.

${ }^{40}$ Gerlis 2016. 